\title{
NS Impactful publishing: the Journal of Neurosurgery and its diamond anniversary (1944-2019)
}

\author{
James T. Rutka, MD, PhD \\ Editor-in-Chief, Journal of Neurosurgery Publishing Group, Charlottesville, Virginia
}

With this landmark issue of the Journal of Neurosurgery (JNS), we celebrate the 75th anniversary of continuous publication of articles in neurosurgery. It is likely not a coincidence that the diamond anniversary of the JNS coincides precisely with the 150th anniversary of the birth of Harvey Cushing. It is possible that some events in life are inextricably and cosmically tied together, such as the birth of the founding father of our specialty, the society named after him that ultimately became the American Association of Neurological Surgeons (AANS), and the journal of this organization-the JNS.

https://thejns.org/doi/abs/10.3171/2018.9.JNS182570

KEYWORDS history; Journal of Neurosurgery; 75th anniversary

$\mathrm{W}$ ITH this landmark issue of the Journal of Neurosurgery (JNS), we celebrate the 75 th anniversary of continuous publication of articles in neurosurgery. I am deeply honored to be serving as the journal's Editor-in-Chief (EIC) on the historic occasion of our diamond anniversary, and to be following in the lineage of the previous sage and prescient stewards who have upheld the traditions and legacy of our journal (Table 1). Much has already been written on the topic of the history of the JNS, and the interested reader is referred to many of the primary articles that recount the origins and development of the JNS over the preceding decades (Fig. 1)..$^{2,4-6,10,14,20} \mathrm{I}$ had an opportunity to review aspects of our history on the occasion of the 70th anniversary of the JNS in 2014, just after I became EIC. ${ }^{14}$ I have also had the privilege of reviewing the many significant contributions of Dr. John Jane Sr. during his tenure as EIC from 1992 to $2013 .{ }^{15}$ Accordingly, here I shall underscore the numerous innovations in scientific publishing that have characterized the JNS through the decades, and I will review our most recent and future directions.

At first, however, I want to acknowledge and celebrate the legacy of our first EIC, Dr. Louise Eisenhardt (1891-
1967), who was not only the first woman President of the Harvey Cushing Society (1938-1939), but also the first in history to give the Cushing Oration, which was delivered on the occasion of the American Association of Neurological Surgeons (AANS) annual meeting in 1965. ${ }^{6}$ Other firsts for Dr. Eisenhardt include her being the first woman to specialize in the nascent field of neuropathology and her guardianship of the first Brain Tumor Registry, which housed detailed information on thousands of Dr. Cushing's patients. ${ }^{6}$ Just as we celebrate Dr. Eisenhardt's legacy here, so I think it is important and appropriate to acknowledge that Dr. Shelly Timmons is serving this year as the first woman neurosurgeon President of the AANS. ${ }^{1}$

In a letter from past EIC Dr. William Collins Jr. to Dr. Jane dated September 26, 1997, Collins underscored the importance of recognizing that the JNS is an "Editorial Board Journal" and not an "Editor's Journal." What this means is that the Editorial Board plays a quintessential role in determining the content of the JNS through the peer review process with minor, but important, influence of the EIC. Since its inception, the peer review process of the Journal has remained sequential rather than simultaneous. As far as I am aware, the JNS is the only academic

ABBREVIATIONS AANS = American Association of Neurological Surgeons; $A$ SPN = American Society of Pediatric Neurosurgeons; EIC = Editor-in-Chief; FOCUS = Neurosurgical Focus; JNS = Journal of Neurosurgery; JNSPG = Journal of Neurosurgery Publishing Group; PEDS = Journal of Neurosurgery: Pediatrics; SPINE = Journal of Neurosurgery: Spine.

SUBMITTED September 4, 2018. ACCEPTED September 13, 2018.

INCLUDE WHEN CITING DOI: 10.3171/2018.9.JNS182570. 
TABLE 1. Previous Editors-in-Chief of the Journal of Neurosurgery

\begin{tabular}{lcl}
\hline \multicolumn{1}{c}{ Editor-in-Chief } & Years of Service & Journal Office Location \\
\hline Louise Eisenhardt & $1944-1965$ & New Haven, CT \\
\hline Henry L. Heyl & $1965-1975$ & Hanover, NH \\
\hline Henry G. Schwartz & $1975-1985$ & St. Louis, MO \\
\hline William F. Collins Jr. & $1985-1989$ & New Haven, CT \\
\hline Thoralf M. Sundt Jr. & $1989-1992$ & Rochester, MN \\
\hline John A. Jane Sr. & $1992-2013$ & Charlottesville, VA \\
\hline
\end{tabular}

journal to follow this practice at this time. While Dr. Jane gave me full rein to run the Journal of Neurosurgery Publishing Group (JNSPG) in any manner I should wish, he did emphasize to me his expectation and strong hope that I would adhere to the legacy of the sequential peer review process during my tenure as EIC.

The Editorial Boards of the JNSPG are worth commenting upon here. They have been kept traditionally small; their members review virtually all submitted articles; and they all serve time-limited terms. At the present time, each Editorial Board member reviews between 100 and 250 manuscripts per year. The Editorial Board cochairs in their final year may each review over 400 manu- scripts. Prospective members of the Editorial Board are voted in at the annual meeting of the AANS each year. Months before the annual meeting, the EIC assists the Editorial Board in identifying potential Editorial Board members, but does not have a vote in determining who the next Editorial Board members will be. The devotion of the Editorial Board members is undeniable, and their dedication to the workload is unassailable. For me, it has been a rare privilege to see how their reviews and knowledge of the literature improve over their terms of service. A full listing of all Editorial Board members and EICs of the JNS since its beginning, as well as their terms of service, is shown in Table 2. As can be seen in this table, the Editorial Board represents a "who's who" in organized neurosurgery. You can also see that the size of the Editorial Board has, of necessity, grown commensurate with the increasing workload and number of submitted manuscripts (see below). But it has also grown to take into account the subspecialization of neurosurgery, the requirement for separate Editorial Boards for each of the print journals, and Neurosurgical Focus (FOCUS).

I have previously reviewed the origins and importance of FOCUS and the Journal of Neurosurgery: Spine (SPINE). ${ }^{14,15,17}$ Here, however, I would like to elaborate further on the establishment of the Journal of Neurosurgery: Pediatrics (PEDS). PEDS arose through the lobbying efforts of Dr. Jane with then President of the American Soci-

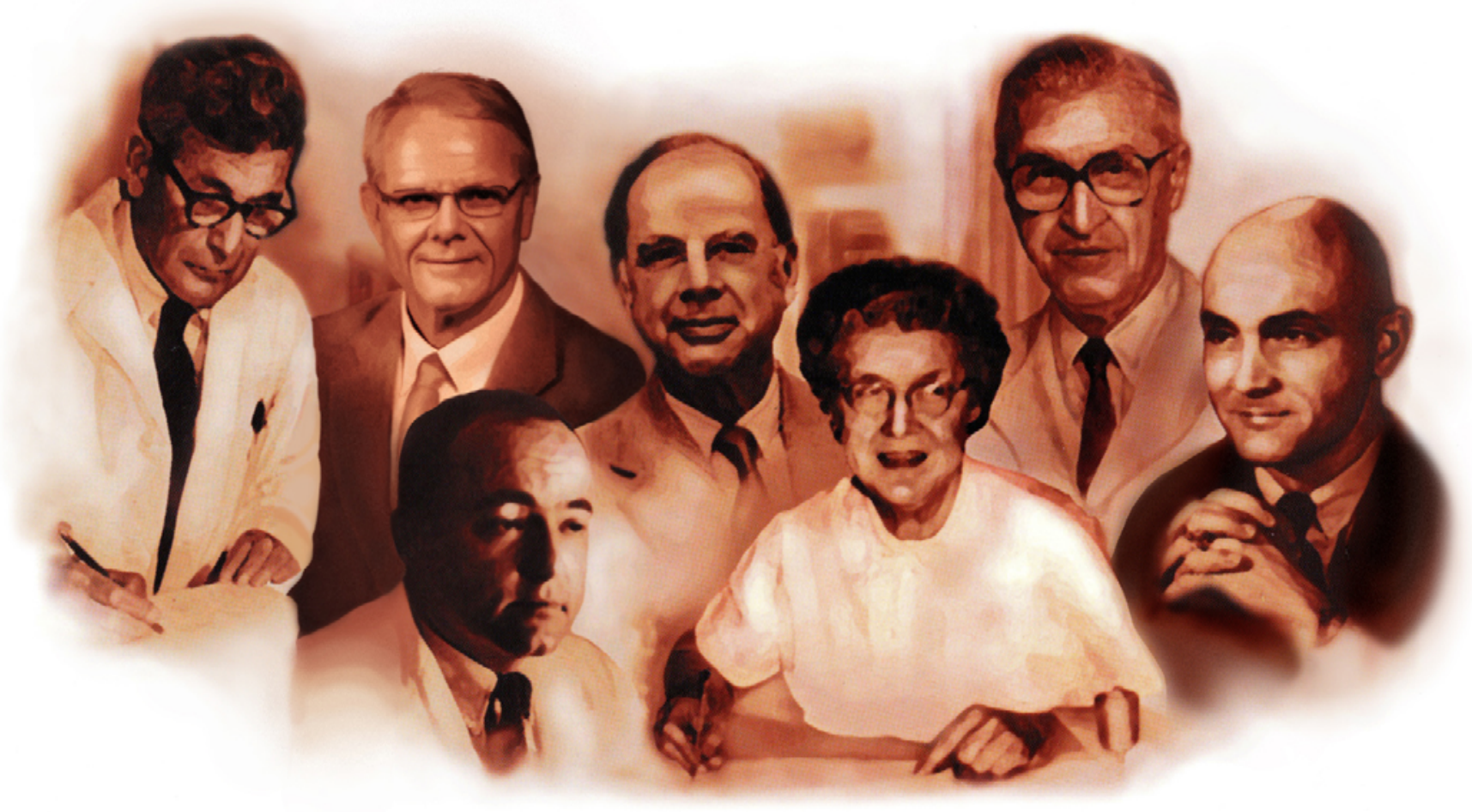

FIG. 1. The Editors of the Journal of Neurosurgery. From left to right: Henry G. Schwartz (1975-1985), James T. Rutka (2013present), John A. Jane Sr. (1992-2013), Henry L. Heyl (1965-1975), Louise Eisenhardt (1944-1965), William F. Collins Jr. (1985-1989), and Thoralf M. Sundt Jr. (1989-1992). Original photo collage by Grove Design, as modified by Stacey Krumholtz. Figure is available in color online only. 
TABLE 2. Editorial Board members of the JNSPG journals

\begin{tabular}{|c|c|c|c|}
\hline \multicolumn{4}{|l|}{ Journal of Neurosurgery } \\
\hline Louise Eisenhardt (1944-1965) & $\begin{array}{l}\text { Thoralf M. Sundt Jr. (1981-1987; } \\
\text { 1989-1992) }\end{array}$ & William Couldwell (1999-2007) & Gregory Zipfel (2013-2018) \\
\hline Gilbert Horrax (1944-1950) & Nicholas T. Zervas (1983-1990) & Dennis Spencer (2000-2004) & Theodore Schwartz (2013-2018) \\
\hline Alfonso Asenjo (1944-1950) & Robert Bourke (1984-1988) & Mitchel Berger (2000-2008) & Andrew Parsa (2014-2015) \\
\hline R. Glen Spurling (1944-1952) & $\begin{array}{l}\text { John A. Jane Sr. (1983-1991; } \\
\text { 1992-2013) }\end{array}$ & $\begin{array}{l}\text { Roberto Heros (2000-2009; } \\
\quad 2010-2014)\end{array}$ & Aaron Dumont (2014-2018) \\
\hline $\begin{array}{l}\text { Kenneth G. McKenzie (1944- } \\
\text { 1954) }\end{array}$ & George A. Ojemann (1984-1992) & Nicolas de Tribolet (2000-2006) & Bob Carter (2014-present) \\
\hline Winchell McK. Craig (1944-1956) & Michael Pollay (1985-1993) & Regis Haid (2001-2004) & Frederick Barker (2015-present) \\
\hline Franc Ingraham (1951-1960) & Bryce K. A. Weir (1985-1994) & Fredric Meyer (2002-2009) & Kevin Cockroft (2015-present) \\
\hline Paul C. Bucy (1951-1960) & Robert L. Grubb Jr. (1986-1995) & Warren Selman (2002-2010) & $\begin{array}{l}\text { Nicholas Bambakidis (2015-pres- } \\
\text { ent) }\end{array}$ \\
\hline Barnes Woodhall (1953-1962) & M. Stephen Mahaley (1986-1991) & Kim Burchiel (2003-2010) & Randy Jensen (2015-present) \\
\hline Bronson S. Ray (1955-1965) & Martin H. Weiss (1986-1995) & Antonio Chiocca (2005-2011) & Michael Kaplitt (2016-present) \\
\hline David L. Reeves (1957-1966) & Robert H. Wilkins (1987-1997) & Andres Lozano (2006-2011) & Howard Riina (2016-present) \\
\hline $\begin{array}{l}\text { Henry G. Schwartz (1959-1968; } \\
\text { 1975-1985) }\end{array}$ & Howard M. Eisenberg (1987-1997) & Giuseppe Lanzino (2007-2012) & Michael Vogelbaum (2016-present) \\
\hline Henry L. Heyl (1965-1975) & Julian T. Hoff (1989-1998) & Douglas Kondziolka (2008-2012) & Aviva Abosch (2017-present) \\
\hline Eben Alexander Jr. (1961-1970) & John P. Girvin (1989-1999) & Marc Mayberg (2008-2013) & Michael Schulder (2017-present) \\
\hline Arthur A. Ward Jr. (1963-1973) & Donald P. Becker (1990-2000) & R. Loch Macdonald (2009-2013) & Louis Kim (2017-2018) \\
\hline Donald Matson (1965-1968) & Edward Laws (1992-2001) & John H. Sampson (2009-2014) & $\begin{array}{l}\text { Sepideh Amin-Hanjani (2018-pres- } \\
\text { ent) }\end{array}$ \\
\hline Charles G. Drake (1967-1976) & Robert A. Ratcheson (1992-2000) & Nicholas Barbaro (2010-2013) & Mark Hamilton (2018-present) \\
\hline Sidney Goldring (1968-1978) & M. Peter Heilbrun (1992-1998) & E. Sander Connolly (2010-2015) & Lynda Yang (2018-present) \\
\hline Lyle A. French (1969-1974) & Charles J. Hodge Jr. (1993-2000) & Jacques Morcos (2010-2011) & John Jane Jr. (2018-present) \\
\hline Thomas W. Langfitt (1971-1980) & Edward H. Oldfield (1994-2001) & W. Jeff Elias (2011-2016) & Justin Fraser (2018-present) \\
\hline Charles B. Wilson (1973-1982) & Ralph G. Dacey Jr. (1995-2002) & Oren Sagher (2011-2016) & \\
\hline John F. Mullan (1975-1984) & H. Richard Winn (1996-2003) & Emad Eskandar (2012-2016) & \\
\hline W. Eugene Stern (1977-1985) & Lawrence F. Marshall (1997-2004) & Brian Hoh (2012-2016) & \\
\hline $\begin{array}{l}\text { William F. Collins Jr. (1979-1984; } \\
\text { 1985-1989) }\end{array}$ & David W. Roberts (1999-2005) & Russell Lonser (2012-2017) & \\
\hline \multirow[t]{2}{*}{ Robert G. Grossman (1981-1989) } & M. Sean Grady (1999-2008) & Rajiv Midha (2013-2017) & \\
\hline & Robert Martuza (1999-2008) & Jason Sheehan (2013-2017) & \\
\hline \multicolumn{4}{|l|}{ Journal of Neurosurgery: Spine } \\
\hline Edward Benzel (1997-2005) & Robert Heary (2008-2014) & Mark Bilsky (2014-2018) & Sigurd Berven (2017-present) \\
\hline Volker Sonntag (1998-2007) & Mark Hadley (2008-2015) & Joseph Cheng (2014-2018) & Paul Park (2017-present) \\
\hline Paul McCormick (2000-2007) & Praveen Mummaneni (2009-2016) & James Harrop (2014-2018) & Jau-Ching Wu (2017-present) \\
\hline Michael Fehlings (2004-2009) & Paul Arnold (2009-2015) & Asdrubal Falavigna (2015-present) & Erica Bisson (2018-present) \\
\hline Vincent Traynelis (2004-2011 & Charles Fisher (2010-2015) & Zoher Ghogawala (2015-present) & Daniel Hoh (2018-present) \\
\hline Christopher Shaffrey (2004-2012) & Langston Holly (2010-2016) & Shekar Kurpad (2016-present) & Michael Steinmetz (2018-present) \\
\hline Ziya Gokaslan (2006-2013) & Lawrence Lenke (2012-2016) & Michael Groff (2016-present) & Sigurd Berven (2017-present) \\
\hline Dennis Vollmer (2006-2012) & Michael Wang (2012-2017) & Daniel Sciubba (2016-present) & \\
\hline Alexander Vaccaro (2006-2013) & Charles Branch (2013-2017) & & \\
\hline Atul Goel (2007-2014) & Michael Kaiser (2013-2017) & & \\
\hline \multicolumn{4}{|l|}{ Journal of Neurosurgery: Pediatrics } \\
\hline $\begin{array}{l}\text { James T. Rutka (1998-2012; } \\
\text { 2013-present) }\end{array}$ & John Kestle (2007-2014) & Howard Weiner (2014-present) & $\begin{array}{l}\text { Elizabeth Tyler-Kabara (2018-pres- } \\
\text { ent }\end{array}$ \\
\hline Ian Pollack (2002-2013) & Mark Souweidane (2008-2015) & David Adelson (2014-present) & Sandi Lam (2018-present) \\
\hline W. Jerry Oakes (2003-2008) & $\begin{array}{l}\text { Ann-Christine Duhaime (2009- } \\
\text { 2016) }\end{array}$ & $\begin{array}{l}\text { Douglas Brockmeyer (2015-pres- } \\
\text { ent) }\end{array}$ & Jay Riva-Cambrin (2018-present) \\
\hline
\end{tabular}


Rutka

" CONTINUED FROM PAGE 3

TABLE 2. Editorial Board members of the JNSPG journals

\begin{tabular}{lll}
\hline \multicolumn{2}{l}{ Journal of Neurosurgery: Pediatrics (continued) } & \\
\hline Frederick Boop (2003-2011) & Jeffrey Ojemann (2010-2016) & Cormac Maher (2015-present) \\
\hline Thomas Pittman (2003-2012) & Corey Raffel (2011-2017) & Matthew Smyth (2016-present) \\
\hline Joseph Piatt (2003-2010) & Jay Wellons (2012-2017) & Nalin Gupta (2016-present) \\
\hline Harold Rekate (2003-2008) & $\begin{array}{c}\text { Shenandoah Robinson (2013- } \\
\text { 2018) }\end{array}$ & Andrew Jea (2017-present) \\
\hline Tae Sung Park (2003-2009) & Abhaya Kulkarni (2013-2018) & Jeffrey Blount (2017-present) \\
\hline R. Michael Scott (2003-2009) & & \\
\hline Marion Walker (2003-2007) & & \\
\hline
\end{tabular}

Years in parentheses represent years of service. Editors-in-Chief and their years of service in this role are identified by italics.

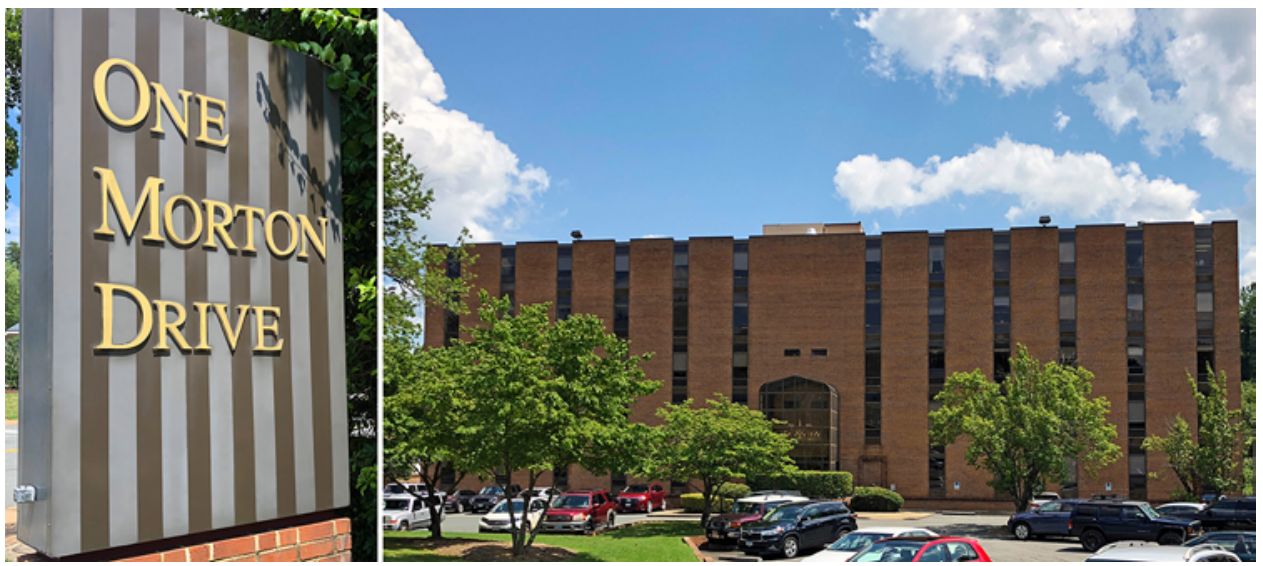

FIG. 2. The JNSPG office, One Morton Drive, Charlottesville, Virginia. The office is located on the second floor of the building with a 3000-square-foot space fully equipped for state-of-the-art journal publishing. Figure is available in color online only.

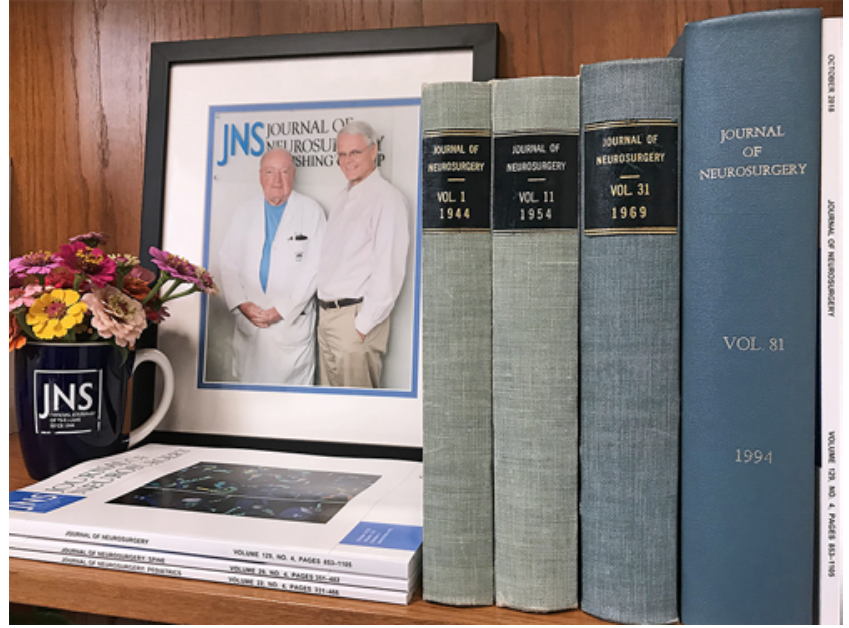

FIG. 3. Bound volumes of the 10th, 25th, and 50th anniversary editions of the JNS. Figure is available in color online only. ety of Pediatric Neurosurgeons (ASPN), Dr. Jerry Oakes. Dr. Jane was quite persuasive in his appeal to Dr. Oakes to have the ASPN "come into the tent" of the JNSPG. At the time, Pediatric Neurosurgery, a Karger publication, was the journal of the ASPN, with a paid readership of over 900 individuals. The advantage for the ASPN to publish with the JNSPG was that the ASPN would have a dramatic, tenfold increase in readership. Dr. Oakes discussed the opportunity of joining the JNSPG at the next annual meeting of the ASPN, in 2003. Following much debate and an $80 / 20$ vote in favor of joining the JNSPG, the ASPN decided to leave Karger to form PEDS (Dr. Oakes, personal communication). Dr. Oakes also acknowledges the strong support he received to join forces with the JNSPG from Drs. Marion (Jack) Walker, University of Utah, and David McLone, Northwestern University. Thus, the first issue of PEDS was published in February 2004.

Currently the JNSPG publishes 12 issues each year for the JNS, SPINE, PEDS, and FOCUS, totaling 48 issues. In addition, there are now 4 video supplements produced as part of FOCUS, and a biannual Gamma Knife meetings supplement thanks to the support and interest of Dr. Danny Leksell and the Leksell Gamma Knife Society. In the past 5 years, we have also published topical guide- 
TABLE 3. Selection of impactful papers published in anniversary years of the Journal of Neurosurgery

\begin{tabular}{|c|c|c|}
\hline Authors & Title of Paper & Impact \\
\hline \multicolumn{3}{|l|}{ 10th Anniversary Volume-1954 } \\
\hline Fulton & Recent advances in neurophysiology & Description of the limbic system \& somatic neocortex function \\
\hline Davis \& Craigmile & $\begin{array}{l}\text { Results of radioactive isotope encephalography } \\
\text { in patients with verified intracranial tumors }\end{array}$ & $\begin{array}{l}\text { Description of the use of radioactive isotope imaging to } \\
\text { visualize brain tumors }\end{array}$ \\
\hline Love \& Svien & $\begin{array}{l}\text { Results of decompression operation for trigemi- } \\
\text { nal neuralgia }\end{array}$ & $\begin{array}{l}\text { A report foreshadowing the use of microvascular decompres- } \\
\text { sion for trigeminal neuralgia }\end{array}$ \\
\hline \multicolumn{3}{|l|}{ 25th Anniversary Volume-1969 } \\
\hline Krayenbühl, Yaşargil, McClintock & $\begin{array}{l}\text { Treatment of spinal cord vascular malformations } \\
\text { by surgical excision }\end{array}$ & $\begin{array}{l}\text { Demonstration of resection of vascular malformations using } \\
\text { operative microscope }\end{array}$ \\
\hline Wilson \& Hoshino & $\begin{array}{l}\text { Current trends in the chemotherapy of brain } \\
\text { tumors with special reference to glioblastoma }\end{array}$ & $\begin{array}{l}\text { Discussion of the beginnings of viable chemotherapy for } \\
\text { glioblastoma }\end{array}$ \\
\hline Davis, Alexander, Kelly & Treatment of craniosynostosis & $\begin{array}{l}\text { Presentation of a systematic approach to single-suture \& } \\
\text { multisuture synostosis }\end{array}$ \\
\hline \multicolumn{3}{|l|}{ 50th Anniversary Volume-1994 } \\
\hline $\begin{array}{l}\text { Zabramski, Wascher, Spetzler, } \\
\text { et al. }\end{array}$ & $\begin{array}{l}\text { The natural history of familial cavernous } \\
\text { malformations }\end{array}$ & $\begin{array}{l}\text { Demonstration of the dynamic nature of cavernous malforma- } \\
\text { tions }\end{array}$ \\
\hline Brem, Tamargo, Olivi, et al. & $\begin{array}{l}\text { Biodegradable polymers for controlled delivery } \\
\text { of chemotherapy with and without radiation } \\
\text { therapy }\end{array}$ & $\begin{array}{l}\text { Description of the use of controlled-release polymers impreg- } \\
\text { nated w/ BCNU for brain tumors }\end{array}$ \\
\hline Oldfield, Muraszko, Shawker & $\begin{array}{l}\text { Pathophysiology of syringomyelia associated } \\
\text { with Yaşargil/Chiari I malformation of the } \\
\text { cerebellar tonsils }\end{array}$ & $\begin{array}{l}\text { Determination of the critical pressure gradient across the } \\
\text { foramen magnum leading to syringomyelia }\end{array}$ \\
\hline
\end{tabular}

lines on the management of pediatric hydrocephalus and lumbar spine disease. The total number of pages for all journals of the JNSPG has increased more than fivefold since 1963 and is now $>7000$ pages yearly. While there were 3604 total submissions in 2012, this number has increased dramatically to $>5500$ submissions in 2018 . The total number of individual subscriptions for the Journal is 10,950 , and the total number of institutional subscriptions is 1475. I am indeed most proud of the Impact Factors for the JNSPG: 4.3 for JNS, 2.8 for SPINE, 2.2 for PEDS, and 2.6 for FOCUS in 2017.

The appointment process of the EIC of the JNS was historically shrouded in secrecy and subterfuge. ${ }^{2}$ Mercifully, this process has now been codified by the AANS. Candidates wishing to stand for the position of EIC are requested to write letters of interest to the JNS EIC Search Committee, which is composed of the outgoing and incoming Editorial Board co-chairs. A slate of potential candidates is then considered and shared with the Executive Committee of the AANS. Approved candidates are interviewed by the EIC Search Committee, and the final selection is made following a vote by the entire Editorial Board at the annual meeting of the AANS. The successful candidate is entitled to serve for 5 years as EIC, with the possibility of serving one additional 5-year term pending approval of the Editorial Board. I was pleased to be named EIC in April 2013 and was fortunate to work stepwise with Dr. Jane in the subsequent months to achieve a fully smooth transition in leadership of the Journal. ${ }^{15}$

I was also very fortunate to have appointed Dr. Douglas Kondziolka, Department of Neurosurgery at New York University (NYU Langone), to the position of Associate

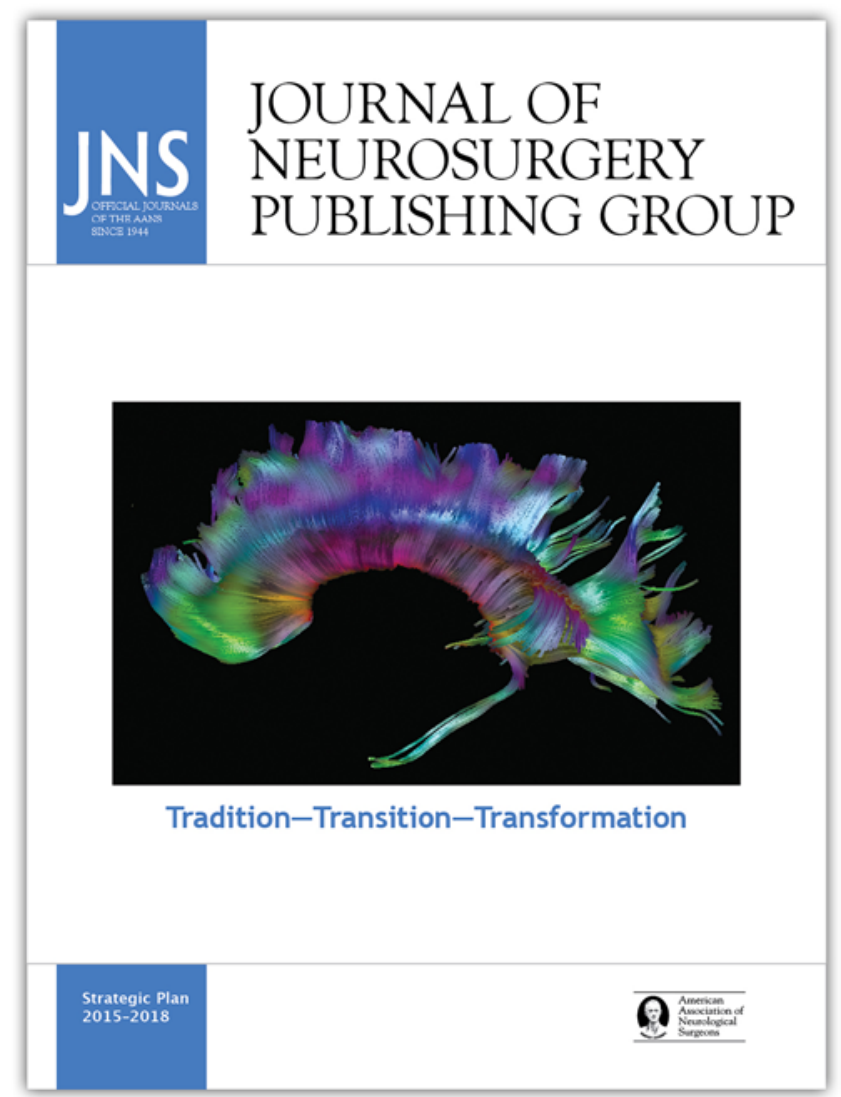

FIG. 4. Cover of the 2015-2018 Strategic Plan of the JNS, entitled "Tradition-Transition-Transformation." Figure is available in color online only. 


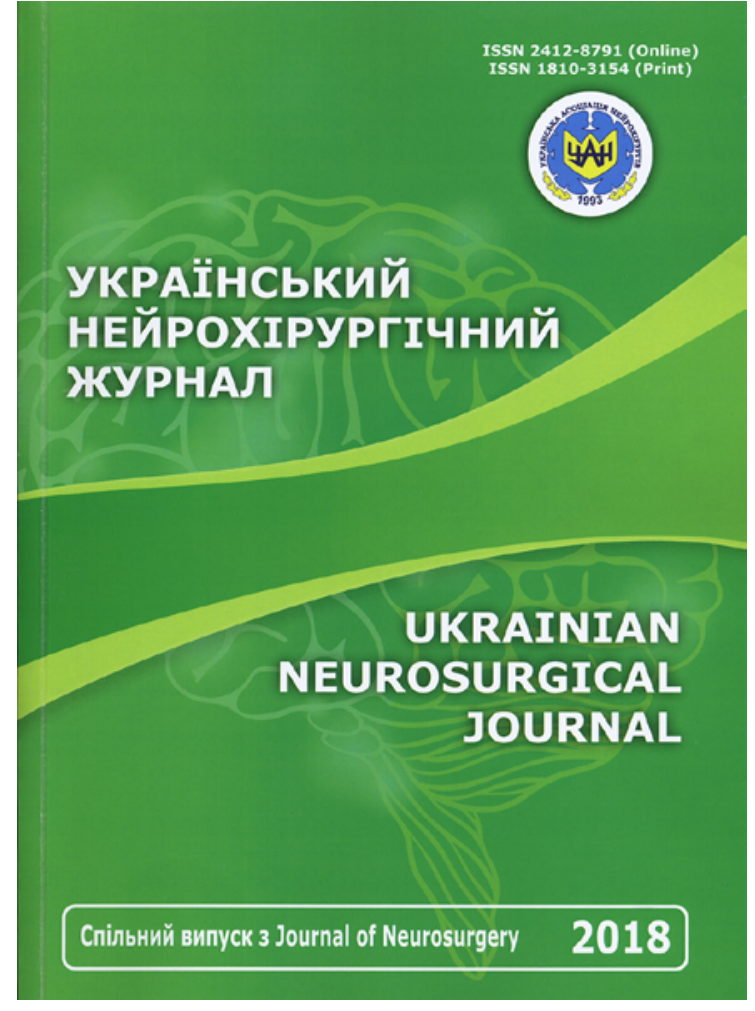

FIG. 5. Global outreach through publication of JNS content in other languages. Shown here is the cover of the journal of the Ukrainian Association of Neurosurgeons, in which JNS brain tumor-related topics are published. Figure is available in color online only.
Editor. Dr. Kondziolka and I have worked together seamlessly to make the Journal as good as it can be. And we have been aided by Dr. William Couldwell, Department of Neurosurgery at the University of Utah, as Editor-in-Chief of Neurosurgical Focus, and Associate Editors Drs. Aaron Cohen-Gadol, Indiana University, and Jason Sheehan, University of Virginia, who have taken Focus to all-time new levels.

The office of the JNSPG resides in Charlottesville, Virginia (Fig. 2). To stay in close contact with the office staff, I routinely travel to the JNSPG office many times each year. In addition, in the months when I am not in Charlottesville, we connect through monthly videoconferences, during which updates from the different departments of the JNSPG are heard, progress made in our Strategic Plan is reviewed, and topical matters in the world of academic publishing are discussed. On my last visit to Charlottesville, July 24-28, 2018, I made a point of reviewing some of the materials in the archives of One Morton Drive. It was my good fortune to pull bound volumes of the JNS from its 10th, 25th, and 50th anniversary years (Fig. 3). I felt empowered to have these historical volumes at my fingertips and to leaf through the numerous articles that chronicle the history of neurosurgical practice and research. It was abundantly evident to me that since its first issue was published in 1944, the JNS has continued to play an integral role in charting the course of neurosurgery for the great benefit of AANS members, neurosurgery trainees, neuroscientists, and allied neurological and surgical specialists around the world. At a glance, I could spot articles within these bound volumes that have truly
(0) Instagram
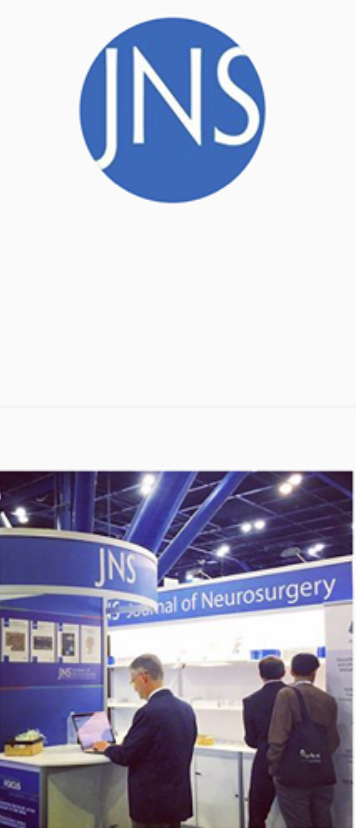

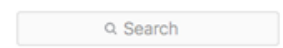

thejnspg Following $\cdots$

283 posts $\quad 18.4 \mathrm{k}$ followers $\quad 204$ following

Journal of Neurosurgery

Journal of Neurosurgery (JNS)

The world's leading journal in \#neurosurgery.

Official journal of the AANS since 1944

Website: TheJNS.org

www.neurosurgicalatlas.com/cases/frontal-sylvian-avm-and-pedicle-mca-ane...

Followed by jk_john, margieboraas, jessicacamposmd +5 more

MOATS TAGGED

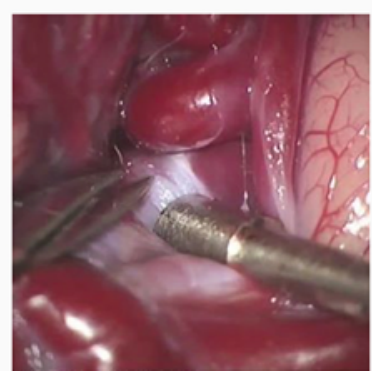

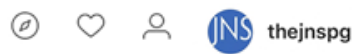
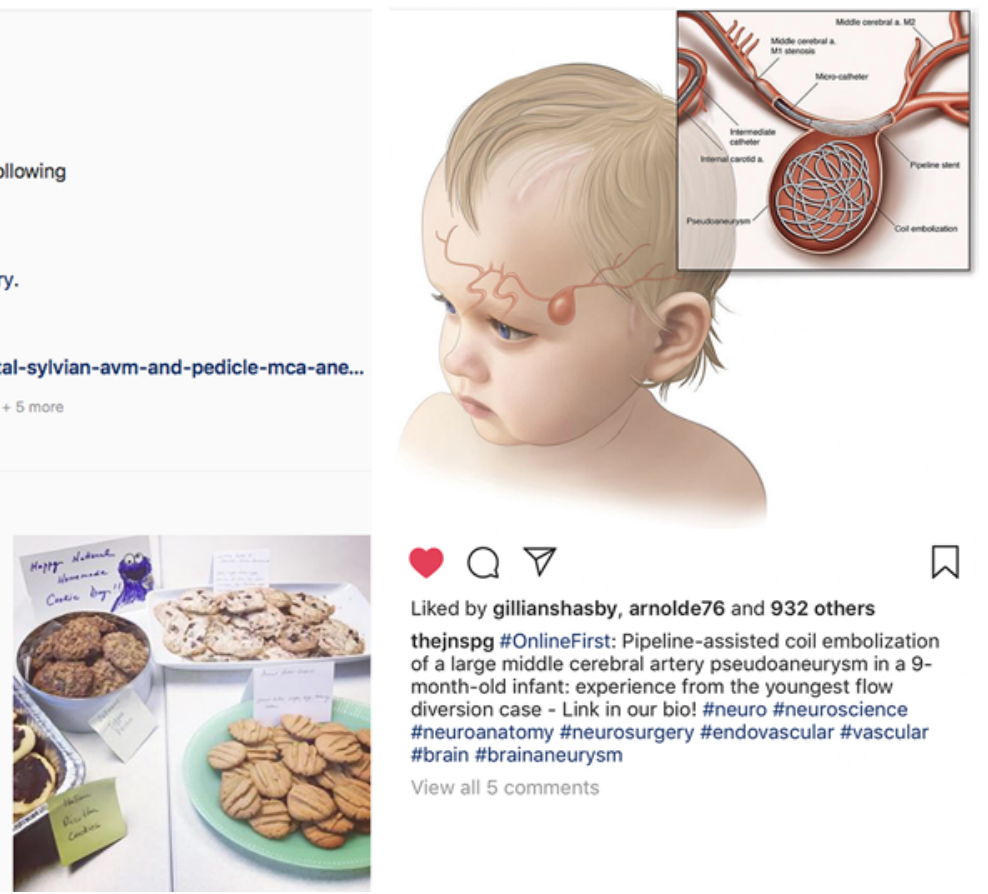

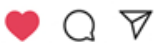

Liked by gillianshasby, arnolde76 and 932 others

thejnspg \#OnlineFirst: Pipeline-assisted coil embolization of a large middle cerebral artery pseudoaneurysm in a 9month-old infant: experience from the youngest flow month-old infant: experience from the youngest flow
diversion case - Link in our bio! \#neuro \#neuroscience diversion case - Link in our bio! \#neuro \#neuroscience \#neuroanatomy \#neurosur
\#brain \#brainaneurysm

View all 5 comments

FIG. 6. Screenshots of the JNS Instagram page (left) and an entry (right). The JNS is the only neurosurgical journal active on Instagram at this time. Figure is available in color online only. 


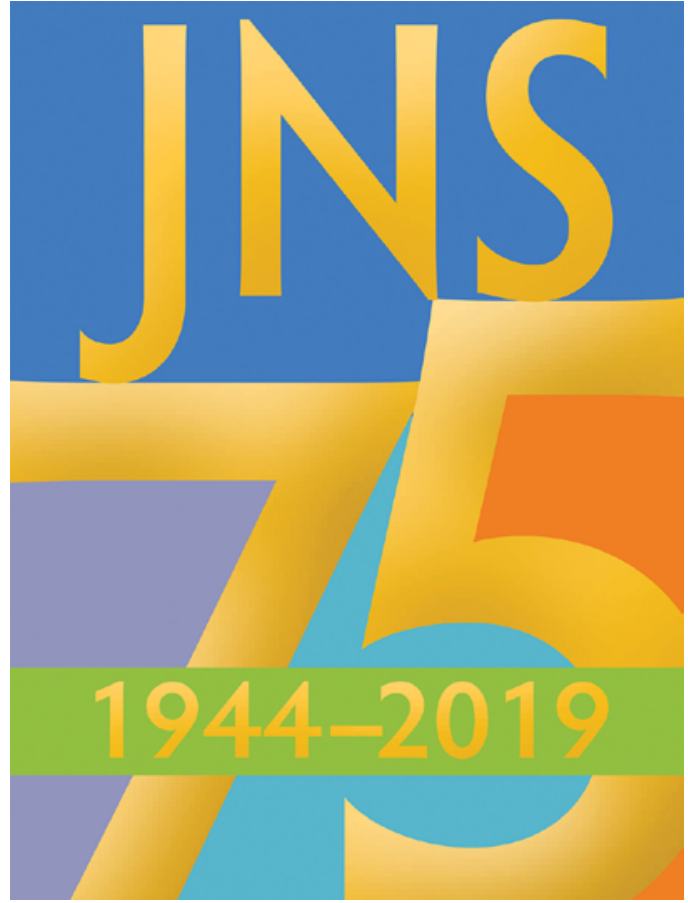

FIG. 7. Logo celebrating the diamond anniversary of the JNS. This logo will appear on the covers of the 2019 issues of all JNSPG publications and will accompany all invited review articles on topics of great interest to neurosurgeons. Logo design by Laura Sutherland. Figure is available in color online only.

influenced our specialty and become landmark and oftencited articles (Table 3)., $3,-9,11-13,21,23$ While bound and print volumes of all issues of the JNS are found in Charlottesville, there are also numerous other archival materials that we hope to digitize and keep as permanent records for the benefit of our specialty.

We have done much these past 5 years to add to the historical legacy of the JNS. Guided by our previous Strategic Plan, "Tradition-Transition-Transformation," we performed a redesign of the cover and layout of the JNS (Fig. 4). ${ }^{18}$ While still known affectionately as the "White Journal," we have added icons for quick online transitions to digital content and have reconfigured the design and appearance of tables and figures. We have formed important collaborations with the Rhoton Collection ${ }^{19}$ and the Neurosurgical Atlas created by Dr. Aaron Cohen-Gadol. ${ }^{16}$ We have established a new category of submissions entitled "Broca's Area," in which timely and important opinion pieces can be promulgated. One of the most attention-garnering articles in recent times was on Michael Jackson's ability to challenge our understanding of spine biomechanics. ${ }^{22}$ As part of our emphasis on global outreach and impact, we have published content in collaboration with other neurosurgical associations around the world, for example, the Ukrainian Association of Neurosurgeons (Fig. 5). Finally, we have launched an active and aggressive social media campaign through the formation of a social media team led by social media manager Dr. Naif Alotaibi of the University of Toronto. In 2017, JNSPG had 42,040 total social media users with 32,929 Facebook likes, 9111 Twitter followers, and a Klout Score of 62, the highest score for any neurosurgical account. This score identifies entities such as the JNSPG that have generated the most engaging and relevant content on a given topic for a period of 90 days. In addition, the JNS is the only neurosurgical journal with a presence on Instagram (Fig. 6).

To help celebrate the JNSPG's 75th year of continuous publishing of neurosurgical articles, we have designed a commemorative logo (Fig. 7), which will adorn all covers and select articles throughout the year. We have launched our new website with advanced features that will keep us at the forefront of timely posting of content and ease of usage. Throughout our 75th year, our print journals will include invited articles by masters in the field. Finally, we take great pride in launching our new Strategic Plan, entitled "Impactful Publishing: Growing Our Legacy." The tagline for this plan truly embodies the history of the JNS and all that it has meant to our specialty since its inception. This plan will be the blueprint for all journal-related activities for the next 5 years, 2019-2024. Assisting me

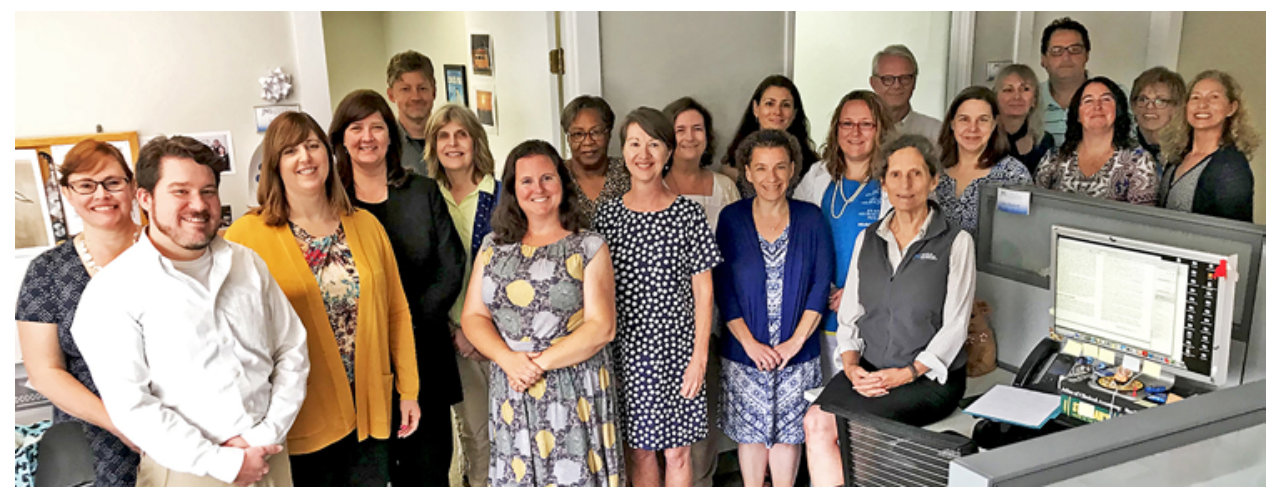

FIG. 8. Photo of JNSPG office staff with AANS President Shelly Timmons and Executive Director Kathleen Craig. From left: Becca White, Michael Baruzzini, Kathleen Craig, Shelly Timmons, Chris Gavin, Linda Sherman, Gillian Shasby, Dorothy Turner, Margie Shreve, Jo Ann Eliason, Sheyanne Armstrong, Elizabeth Arnold, Sam Geouge, James Rutka, Anne Stanford, Jenn Wathen, Mary Beth Yeaton, Paul Pugh, Jennifer John, Laura Sutherland, and Kate Mason. Not pictured: James Dell, Kenneth Fox, and Donna Goodrich. Figure is available in color online only. 


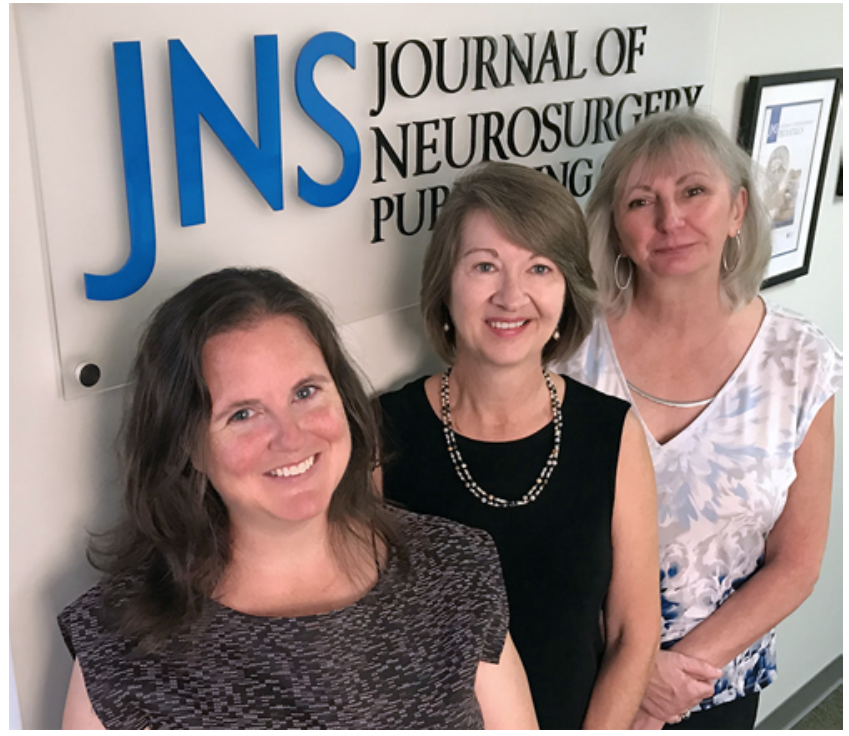

FIG. 9. Photo of JNSPG Director of Publications Gillian Shasby (left), Executive Assistant to the Editors-in-Chief Margie Shreve (center), and Director of Finance Mary Beth Yeaton (right). Figure is available in color online only.

in reaching the goals of our plan will be the 21 dedicated staff members from the Charlottesville office led by the Directors of Publications and Finance-Gillian Shasby and Mary Beth Yeaton-who have followed a long line of superlative and talented managing editors (Fig. 8). I also want to give special recognition and thanks to Margie Shreve, who began working with the Journal under Dr. Thoralf Sundt Jr. at the Mayo Clinic in Rochester, Minnesota. Margie relocated to Charlottesville after Dr. Sundt's passing in 1992 and became Dr. Jane's confidant and able assistant for the next 21 years. I have had the great benefit of working directly with Margie since my appointment as EIC in 2013 (Fig. 9).

I want to conclude by thanking the AANS for its unwavering support of the JNS. The current relationship between the JNSPG and the AANS has never been better, in my opinion. It is likely not a coincidence that the diamond anniversary of the JNS coincides precisely with the 150th anniversary of the birth of Harvey Cushing. It is possible that some events in life are inextricably and cosmically tied together, such as the birth of the founding father of our specialty, the society named after him that ultimately became the AANS, and the journal of this organizationthe JNS. As with a diamond, let us all hope that the importance and value of the JNS will endure forever!

\section{References}

1. Abosch A, Rutka JT: Women in neurosurgery: inequality redux. J Neurosurg 129:277-281, 2018

2. Alexander E Jr: Evolution of the Journal of Neurosurgery. $\mathbf{J}$ Neurosurg 80:762-766, 1994

3. Brem H, Tamargo RJ, Olivi A, Pinn M, Weingart JD, Wharam M, et al: Biodegradable polymers for controlled delivery of chemotherapy with and without radiation therapy in the monkey brain. J Neurosurg 80:283-290, 1994

4. Bucy PC: The Journal of Neurosurgery. Its origin and development. J Neurosurg 80:160-165, 1994

5. Davey LM: John F. Fulton, M.D., and the founding of the Journal of Neurosurgery. J Neurosurg 80:584-587, 1994

6. Davey LM: Louise Eisenhardt, M.D.: first editor of the Journal of Neurosurgery (1944-1965). J Neurosurg 80:342346,1994

7. Davis CH Jr, Alexander E Jr, Kelly DL Jr: Treatment of craniosynostosis. J Neurosurg 30:630-636, 1969

8. Davis L, Craigmile T: Results of radioactive isotope encephalography in patients with verified intracranial tumors. J Neurosurg 11:262-267, 1954

9. Fulton JF: Recent advances in neurophysiology. J Neurosurg 11:1-6, 1954

10. Jane JA Sr: Editorial comment. The golden anniversary celebration of the Journal. J Neurosurg 80:1-2, 1994

11. Krayenbühl H, Yaşargil MG, McClintock HG: Treatment of spinal cord vascular malformations by surgical excision. J Neurosurg 30:427-435, 1969

12. Love JG, Svien HJ: Results of decompression operation for trigeminal neuralgia. J Neurosurg 11:499-504, 1954

13. Oldfield EH, Muraszko K, Shawker TH, Patronas NJ: Pathophysiology of syringomyelia associated with Chiari I malformation of the cerebellar tonsils. Implications for diagnosis and treatment. J Neurosurg 80:3-15, 1994

14. Rutka JT: Editorial. The Journal of Neurosurgery at 70: the legacy continues. J Neurosurg 121:1295-1296, 2014

15. Rutka JT: Editorial. Leading transition while maintaining tradition. J Neurosurg 119:1-3, 2013

16. Rutka JT: Editorial. Mastering the art of complex neurosurgical procedures: The Neurosurgical Atlas and the Journal of Neurosurgery. J Neurosurg 126:1029-1032, 2017

17. Rutka JT: Editorial. Neurosurgical Focus: first among equals in online, freely accessible journals. Neurosurg Focus 40(4):E1, 2016

18. Rutka JT: Editorial. A new look for JNSPG publications: the anatomy of redesign. J Neurosurg 122:1-3, 2015

19. Rutka JT: Editorial. The Rhoton Collection and the Journal of Neurosurgery: expanding the reach of neuroanatomy in the digital print world. J Neurosurg 125:4-6, 2016

20. Schwartz HG: History of the Journal of Neurosurgery, 19651980. J Neurosurg 80:939-940, 1994

21. Wilson CB, Hoshino T: Current trends in the chemotherapy of brain tumors with special reference to glioblastomas. J Neurosurg 31:589-603, 1969

22. Yagnick NS, Tripathi M, Mohindra S: How did Michael Jackson challenge our understanding of spine biomechanics? J Neurosurg Spine 29:344-345, 2018

23. Zabramski JM, Wascher TM, Spetzler RF, Johnson B, Golfinos J, Drayer BP, et al: The natural history of familial cavernous malformations: results of an ongoing study. $\mathbf{J}$ Neurosurg 80:422-432, 1994

\section{Disclosures}

The author reports no conflict of interest.

\section{Correspondence}

James T. Rutka: The Hospital for Sick Children, Toronto, ON, Canada.james.rutka@sickkids.ca. 